\title{
Correction: Surfaceome CRISPR screen identifies OLFML3 as a rhinovirus-inducible IFN antagonist
}

Hong Mei ${ }^{1 \dagger}$, Zhao Zha ${ }^{1 \dagger}$, Wei Wang ${ }^{1 \dagger}$, Yusang Xie ${ }^{2}$, Yuege Huang ${ }^{1,3}$, Wenping $\mathrm{Li}^{1,3}$, Dong Wei ${ }^{4}$, Xinxin Zhang ${ }^{4}$, Jieming $\mathrm{Qu}^{2^{*}}$ and Jia Liu ${ }^{1,5,6,7,8^{*}}$

The original article can be found online at https://doi.org/10.1186/ s13059-021-02513-w.

* Correspondence: jmqu0906@163. com; liujia@shanghaitech.edu.cn ${ }^{+}$Hong Mei, Zhao Zha and Wei Wang contributed equally to this work.

${ }^{2}$ Department of Respiratory and Critical Care Medicine, Ruijin Hospital and Institutes of Respiratory Diseases, School of Medicine, Shanghai Jiao Tong University, Shanghai 200025, China ${ }^{1}$ Shanghai Institute for Advanced Immunochemical Studies and School of Life Science and Technology, ShanghaiTech University, Shanghai 201210, People's Republic of China Full list of author information is available at the end of the article
Correction to: Genome Biol 22, 297 (2021).

https://doi.org/10.1186/s13059-021-02513-w

Following publication of the original article [1], the authors identified an error in the author affiliations presented in additional file 1. The additional file has been updated and published in this correction.

The original article [1] has been corrected.

\section{Supplementary Information}

The online version contains supplementary material available at https://doi.org/10.1186/s13059-021-02534-5.

Additional file 1: Fig. S1. Construction of CRISPR genome-wide and surfaceome libraries. Fig. S2. Quality analyses of constructed genome-wide and surfaceome CRISPR libraries. Fig. S3. Evaluation of surfaceome and genome-wide CRISPR libraries. Fig. S4. Validation of the screening results. Fig. S5. Determination of gene modification efficiency. Fig. S6. Validation of the top 10 hits from surfaceome and genome-wide screens. Fig. S7. Construction and validation of single clones of ICAM-1 ${ }^{-/-}$, RAB5C $\mathrm{C}^{-/-}, \mathrm{OLFML}^{-/-}, \mathrm{SLC}_{\mathrm{CA}} 7^{-/-}$and ATP6AP1 ${ }^{-/+} \mathrm{H1} 1-\mathrm{Hela}$ cells. Fig. S8. Validation of the effects of ICAM-1, RAB5C and OLFML3 on RV infection, related to Fig. 3. Fig. S9. Dissection of the functions of RAB5C and OLFML3 in RV infection. Fig. S10. RNA-seq analyses of the effects of RAB5C knockout on RV infection. Fig. S11. RNA-Seq analyses of the effects of OLFML3 on RV infection (related to Fig. 4). Fig. S12. Bar plots showing RT-qPCR quantification of ISG expression in mock and OLML3-/- cells at $24 \mathrm{~h}$ post infection of RV-B14 (a) and RV-A16 (b) at an MOI of 2

\section{Author details}

'Shanghai Institute for Advanced Immunochemical Studies and School of Life Science and Technology, ShanghaiTech University, Shanghai 201210, People's Republic of China. ${ }^{2}$ Department of Respiratory and Critical Care Medicine, Ruijin Hospital and Institutes of Respiratory Diseases, School of Medicine, Shanghai Jiao Tong University, Shanghai 200025, China. ${ }^{3}$ University of Chinese Academy of Sciences, Beijing 100049, China. ${ }^{4}$ Research Laboratory of Clinical Virology, Ruijin Hospital, Shanghai Jiaotong University School of Medicine, Shanghai 200025, China. ${ }^{5}$ Shanghai Clinical Research and Trial Center, Shanghai 201210, People's Republic of China. 'State Key Laboratory of Respiratory Disease, Guangzhou Medical University, Guangzhou 510182, Guangdong Province, China. ${ }^{7}$ Gene Editing Center, School of Life Science and Technology, ShanghaiTech University, Shanghai 201210, People's Republic of China. ${ }^{8}$ Guangzhou Laboratory, No. 9 XingDaoHuanBei Road, Guangzhou International Bio Island, Guangzhou 510005, Guangdong Province, China.

\section{$\triangle B M C$}

(c) The Author(s). 2021 Open Access This article is licensed under a Creative Commons Attribution 4.0 International License, which permits use, sharing, adaptation, distribution and reproduction in any medium or format, as long as you give appropriate credit to the original author(s) and the source, provide a link to the Creative Commons licence, and indicate if changes were made. The images or other third party material in this article are included in the article's Creative Commons licence, unless indicated otherwise in a credit line to the material. If material is not included in the article's Creative Commons licence and your intended use is not permitted by statutory regulation or exceeds the permitted use, you will need to obtain permission directly from the copyright holder. To view a copy of this licence, visit http://creativecommons.org/licenses/by/4.0/. The Creative Commons Public Domain Dedication waiver (http://creativecommons.org/publicdomain/zero/1.0/) applies to the data made available in this article, unless otherwise stated in a credit line to the data. 
Reletishoel online: 15 November 2021

1. Mei H, Zha Z, Wang W, Xie Y, Huang Y, Li W, et al. Surfaceome CRISPR screen identifies OLFML3 as a rhinovirusinducible IFN antagonist. Genome Biol. 2021;22(1):297. https://doi.org/10.1186/s13059-021-02513-w.

\section{Publisher's Note}

Springer Nature remains neutral with regard to jurisdictional claims in published maps and institutional affiliations.

Ready to submit your research? Choose BMC and benefit from:
- fast, convenient online submission
- thorough peer review by experienced researchers in your field
- rapid publication on acceptance
- support for research data, including large and complex data types
- gold Open Access which fosters wider collaboration and increased citations
- maximum visibility for your research: over 100M website views per year
At BMC, research is always in progress.
Learn more biomedcentral.com/submissions

